\title{
Assessing the Utility of Ultraviolet Irradiation to Reduce Bacterial Biofilms in Fish Hatchery Well Water Supplies
}

Natalie Redman*, Christopher Good and Brian J Vinci

The Conservation Fund Freshwater Institute, Shepherdstown, West Virginia, USA

\begin{abstract}
The accumulation of bacterial biofilms and consequent clogging of screens, pipes, and heat exchanger equipment is problematic for water supply systems contaminated with iron bacteria and other slime forming bacteria. Despite the ubiquitous threat posed by iron bacteria contamination in groundwater sources, limited research has focused on physical treatments to address this issue. We sought to investigate the effectiveness of ultraviolet (UV) irradiation on inactivating iron bacteria and slime forming bacteria in a fish hatchery supply water known to have issues with bacterial biofilms. Biological activity reaction tests (BART) were used to analyze the presence or absence of iron related and slime forming bacteria in raw well water at UV dosages of $0 \mathrm{~mJ} / \mathrm{cm}^{2}, 15 \mathrm{~mJ} / \mathrm{cm}^{2}, 30 \mathrm{~mJ} / \mathrm{cm}^{2}, 45$ $\mathrm{mJ} / \mathrm{cm}^{2}$ and $60 \mathrm{~mJ} / \mathrm{cm}^{2}$. Results suggest that UV treatment decreases iron bacteria survival, with the highest percent of non-reactive BART TM test vials resulting from $45 \mathrm{~mJ} / \mathrm{cm}^{2}$ and $60 \mathrm{~mJ} / \mathrm{cm}^{2} \mathrm{UV}$ exposure; however, data regarding UV inactivation of slime forming bacteria were inconclusive. These initial 'proof of concept' findings can be used to design pilot UV water treatment systems for fish hatcheries known to have iron bacteria problems. Pilot treatment system testing can then provide the necessary results to ensure that UV treatment is effective against site-specific iron bacteria populations before full-scale treatment systems are implemented.
\end{abstract}

Keywords: Iron bacteria; UV treatment; Well water; Fish hatchery

\section{Introduction}

Iron-related bacteria are common in aerobic environments where ferrous iron is present, including well water systems, sewage systems, and mining operations [1-3]. Numerous genera of bacteria with varying morphological and physiological characteristics are classified as iron bacteria; these include Gallionella, Crenothrix and Leptothrix [2,3]. Iron bacteria oxidize ferrous iron to the ferric iron state in the form of iron oxide precipitate. Iron bacteria accomplish this oxidation by altering the surrounding redox conditions while harnessing the energy for metabolic function [1-5]. In flowing water, iron concentrations of $0.2 \mathrm{mg} / \mathrm{L}$ to $1.0 \mathrm{mg} / \mathrm{L}$ are sufficient to promote growth of iron-related bacteria $[1,6]$. Iron bacteria growth is easily recognizable due to its thick, $\mathrm{red} /$ brown-colored slime. The slime is a ferric hydroxide precipitation, a form of extracellular polysaccharide polymer produced by the bacteria $[1,5,7]$. Excessive slime growth can be problematic when it leads to clogging of openings, biofouling of pipes and filters, and carbon-steel corrosion $[2,3,5]$.

Aquaculture facilities that use well water sources are potentially subject to the complications associated with the presence of iron bacteria. Excessive biofilms from iron bacteria or other slime-forming bacteria can significantly reduce the efficiency of process water heating and chilling equipment, aeration equipment, and fish culture operations. The clumping nature of iron bacteria cells combined with their cell coating, which contains ferric and manganic salts, act as a barrier to bactericidal agents. This protective characteristic makes killing ironbacteria bacteria difficult $[2,7]$. In well water systems contaminated with iron bacteria, shock chlorination is commonly used as a form of chemical control for iron bacteria [2,8]; however, chlorine is acutely toxic to fish, making the ongoing use of chlorination to treat iron bacteria in aquaculture well water supplies problematic. An alternative bacterial disinfection process is ultraviolet (UV) irradiation. Ultraviolet irradiation is a common physical treatment for a variety of bacterial species, as it effectively interferes with the process of DNA replication via the creation of thymine dimers [9]. The UV dose necessary for bacterial treatment, however, is species specific, and limited information is available regarding the necessary UV dose for the inactivation of ironrelated bacteria and other slime-forming bacteria $[2,9]$.

The goal of this study was to determine the UV dose required for the inactivation of iron-related bacteria and other slime-forming bacteria in raw well water known to have issues with iron-bacteria biofouling. Aliquots of raw well water were exposed to increasing dosages of UV irradiation via a collimated beam apparatus to identify the minimum dosage for the effective treatment of iron-related bacteria and other slime-forming bacteria. These trials were conducted to analyze the relationship between increasing UV dose and chance of survival for iron-related bacteria and slime-forming bacteria.

\section{Materials and Methods}

\section{Test water}

A water sample was obtained from the well water supply for New York State's Department of Environmental Conservation Salmon River Fish Hatchery (Altmar, NY, USA) by submerging a $1 \mathrm{~L}$ autoclaved polypropylene bottle in the hatchery's well water supply headbox, which had clearly observable biofilms present. The water sample was promptly placed on ice and shipped overnight to The Conservation Fund Freshwater Institute (TCFFI; Shepherdstown, WV, USA), where experimentation was initiated within 30 hours of sample collection. Raw water sample chemistry was analyzed prior to the beginning of the study (Table 1).

*Corresponding author: Natalie Redman, The Conservation Fund Freshwater Institute, 1098 Turner Road, Shepherdstown, West Virginia, USA, Tel: +1 304876-2815; E-mail: nredman@conservationfund.org

Received August 08, 2017; Accepted August 29, 2017; Published August 31 2017

Citation: Redman N, Good C, Vinci BJ (2017) Assessing the Utility of Ultraviolet Irradiation to Reduce Bacterial Biofilms in Fish Hatchery Well Water Supplies. J Aquac Res Development 8: 501. doi: 10.4172/2155-9546.1000501

Copyright: () 2017 Redman N, et al. This is an open-access article distributed under the terms of the Creative Commons Attribution License, which permits unrestricted use, distribution, and reproduction in any medium, provided the original author and source are credited. 


\section{UV collimated beam apparatus}

A bench-top collimated beam apparatus (UV Technologies LLC, Collegeville, PA, USA) was utilized to expose the water samples to increasing UV dosages (Figure 1). The apparatus was equipped with a 34 watt, low-pressure, mercury amalgam T5 lamp having 11 watts of UV-C energy. In operation, UV light is directed through a collimating tube with a roughened inner surface to provide homogenous irradiance over the area where the sample is located. A light sensor (Model SEL240, International Light Inc., Newburyport, MA, USA) connected to a radiometer/photometer (Model IL-1400A, International Light Inc.) was employed to measure the amount of UV light emitted from the collimated beam apparatus. The sensor and radiometer were factory calibrated before starting the study. Measurements of irradiance at the center of the sample area were made prior to the start of each sample exposure and at the end of each sample exposure. Ambient air temperature was held constant throughout the testing at $20^{\circ} \mathrm{C}$ to ensure stability of the UV lamp output.

UV dose calculation: Fluence doses $\left(\mathrm{mJ} / \mathrm{cm}^{2}\right)$ were determined per Bolton and Linden's protocol, considering the initial measured incident light $\left(\mu \mathrm{W} / \mathrm{cm}^{2}\right)$, petri factor, reflection factor, water factor,

\begin{tabular}{|c|c|}
\hline Analyte & Concentration \\
\hline Temperature & $9.43^{\circ} \mathrm{C}$ \\
\hline $\mathrm{pH}$ & 7.60 \\
\hline Dissolved oxygen & $7.69 \mathrm{mg} / \mathrm{L}$ \\
\hline Carbon dioxide & $6.61 \mathrm{mg} / \mathrm{L}$ \\
\hline Total iron & $0.424 \mathrm{mg} / \mathrm{L}$ \\
\hline Dissolved iron & $0.0108 \mathrm{mg} / \mathrm{L}$ \\
\hline Ferrous iron & $0.100 \mathrm{mg} / \mathrm{L}$ \\
\hline
\end{tabular}

Table 1: Water chemistry of deep well raw water in aquaculture system at Salmon River Fish Hatchery, NY.

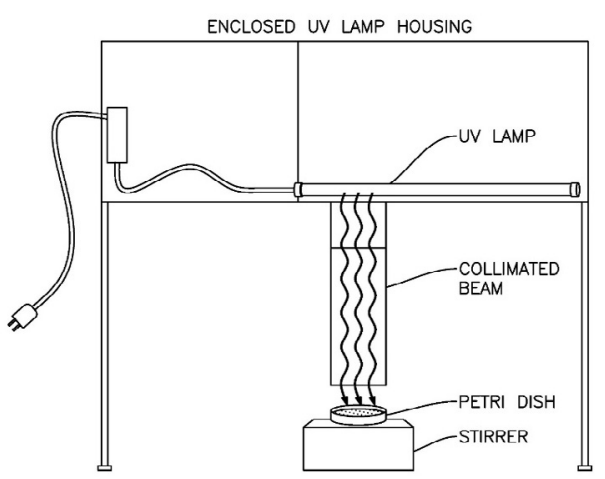

Figure 1: Graphic depicting the collimated beam apparatus set up with petri dish and stir plate necessary for UV treatment of aquaculture raw water.

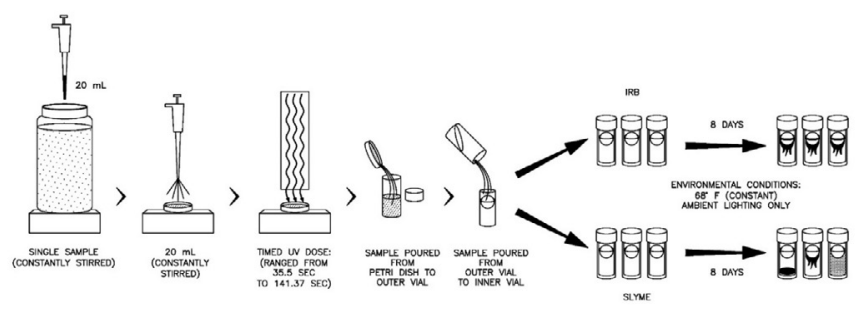

Figure 2: Graphic depicting the process of UV treatment of the raw water and application of BART ${ }^{\mathrm{TM}}$ for analysis of iron related and slime forming bacteria. divergence factor, and duration of exposure (sec) for the water samples (Equation 1). The UV lamp in the collimated beam apparatus was turned on ten minutes prior to testing to ensure stable UV output during the testing. The initial incident light $\mathrm{E}_{0}$ was measured to be 541 $\mu \mathrm{W} / \mathrm{cm}^{2}$. Correction factors for uneven UV irradiance (petri factor), reflection of UV energy at the water surface (reflection factor), and absorption of UV energy in water (water factor) were determined prior to sample testing for accurate estimation of the average UV irradiance $\left(\mathrm{E}_{\text {avg }}\right)$. The petri factor was calculated to be 0.861 by measuring the UV irradiance from the collimated beam apparatus on a 5-mm grid of the petri dish area and averaging those values $(n=88)$ normalized to the value in the center of the area, $\mathrm{E}_{0}$. A reflection factor of 0.975 was used to account for changes in light refractive indices from air to water. The water factor of 0.977 was calculated based on concentration (a) of UV transmittance $\left(0.020 \mathrm{~cm}^{-1}\right)$ and the vertical path length (l) of the sample water in the petri dish $(1 \mathrm{~cm})$. UV Transmittance was analyzed following Hach company's method 10054 [10,11] adapted from APHA method 5910 [12]. The water factor corrected for how much irradiance was absorbed in the water sample as the UV beam passes through it (Equation 1). The divergence factor was calculated to be 0.962 , using the distance (L) from the UV lamp to the surface of the water (25 $\mathrm{cm}$ ) and the path length of the cell suspension (l) (Equation 2). The correction factors were multiplied together to calculate the average UV irradiance from the collimated beam apparatus for the $55-\mathrm{mm}$ petri dish used throughout experimentation (Equation 3) [10].

$$
\begin{aligned}
& \text { Water Factor }=\frac{1-10^{-a l}}{\text { alln }(10)} \\
& \text { Divergence Factor }=\frac{L}{(L+1)} \\
& E_{\text {avg }}=E_{0} \times \text { Petri Factor } \times \text { Reflection Factor } \times \\
& \text { Water Factor } \times \text { Divergence Factor }
\end{aligned}
$$

UV doses required for each treatment by were created adjusting the time of exposure to the UV lamp under the collimated beam apparatus.

\section{UV dose application}

Aliquots of the raw water sample were subjected to five UV doses: 0 (control), $15 \mathrm{~mJ} / \mathrm{cm}^{2}, 30 \mathrm{~mJ} / \mathrm{cm}^{2}, 45 \mathrm{~mJ} / \mathrm{cm}^{2}$ and $60 \mathrm{~mJ} / \mathrm{cm}^{2}$, to determine the UV dose necessary to prevent the growth of iron-related bacteria and slime-forming bacteria. Triplicate testing of each of the UV doses was completed in random order per Bolton and Linden. Each test was started by transferring $20 \mathrm{~mL}$ of the raw well water using a sterile-tipped pipette into a new $55 \mathrm{~mm}$ diameter petri dish. The petri dish with water sample was placed on an adjustable stir plate and stirred with a $7 \mathrm{~mm}$ stir bar at a constant speed. The stirring speed was set to be slow enough to prevent the formation of a vortex in the sample. A solid metal sheet was placed over the top of the petri dish and the covered petri dish with stir plate was moved underneath the collimated beam tube (Figure 2). The metal sheet was removed at the start of a stop watch, and the sample in the petri dish was exposed for a set time per the UV dose required, after which the metal sheet was placed back over the top of the petri dish and the sample was removed from beneath the UV collimated beam apparatus.

\section{BART $^{\mathrm{m}}$ reaction analysis}

Following the required UV exposure for the dose being tested, samples were analyzed using slime-forming (SLYM) and iron-related (IRB) field biological activity reaction tests (BART"). BART ${ }^{\prime \prime}$ analysis followed the protocol of Droyocon Bioconcepts, Inc. [13]. The iron- 
related bacteria detected with the IRB BART ${ }^{\mathrm{TM}}$ test include Gallionella, Pseudomonas, Enterobacter, Citrobacter, and Serratia [13]. The SLYME BART $^{\mathrm{TM}}$ test detects Micrococcus, Proteus, Pseudomonas aeruginosa, Pseudomonas fluorescens, and Zoogloea slime-forming bacteria [13].

BART $^{\prime \prime}$ testing was initiated by first removing the $7 \mathrm{~mm}$ stir bar from the previously UV-treated water sample. The 20 - $\mathrm{mL}$ water sample in the petri dish was then poured into the outer BART" vial, from which $15 \mathrm{~mL}$ was then poured into the inner BART" vial. The IRB inner vial contained Winogradsky's medium and the SLYME inner vial contained Postgate's medium to promote bacterial growth of the respective target genera [13]. The vial also contained a floating interceding device (FID), i.e., a floating ball, to prevent oxygen diffusion into the sample below, permitting the growth of aerobic and anaerobic bacteria (Figure 2). The BART ${ }^{\prime \prime}$ vials were placed out of direct sunlight and maintained at ambient air temperature of $20^{\circ} \mathrm{C}$ for eight days. Pictures were taken daily at 1:00 PM and examined to estimate the number of days until the start of a reaction. BART ${ }^{\prime \prime}$ tests were considered positive for bacterial growth at the start of a visible reaction in the vials, as outlined by the manufacturer's specifications [13]. The IRB BART ${ }^{\mathrm{m}}$ tests were considered positive when a brown/orange ring became evident surrounding the FID. The brown/orange growth indicates the presence of iron oxidizers, such as sheathed iron bacteria or Gallionella [13]. The SLYM BART"' tests were considered positive when the water sample began to turn cloudy due to formation of extracellular polymeric substances. The day on which a reaction started was recorded. The number of days until the reaction started allowed for an estimation of the population size of iron-related bacteria and slime-forming bacteria in the UV treated samples at the start of the BART" testing.

\section{Data analysis}

BART $^{\mathrm{TM}}$ test vials were considered "non-reactors" when there was no reaction observed over the eight-day period, indicative of effective UV treatment of iron-related bacteria and slime-forming bacteria populations. For statistical analyses, Cox proportional hazards models were applied to assess the relationship between increasing UV dose and time-to-failure (i.e., a positive reaction), indicating bacterial growth, using both IRB and SLYM datasets. Schoenfeld residuals were assessed to test the assumptions of the Cox proportional hazards models. Statistical modeling was carried out using STATA software (StataCorp, College Station, TX, USA).

\section{Results and Discussion}

BART $^{\mathrm{TM}}$ test vials were considered positive, i.e., bacteria populations present, following the guidelines of the manufacturer [13]. Reactive IRB BART ${ }^{\mathrm{TM}}$ test vials had an orange/brown growth ring around the FID which would eventually diffuse downwards to the bottom of the vial on subsequent days. This can be observed in control $\left(0 \mathrm{~mJ} / \mathrm{cm}^{2}\right)$ IRB BART ${ }^{\mathrm{TM}}$ test vials at the end of the trial (Figure $3 \mathrm{~A}$ ). Non-reactive IRB BART ${ }^{\mathrm{TM}}$ test vials did not have any brown or orange coloration, rather vials exhibited the green-colored nutrients at the bottom of the vial gradually diffusing upward over the course of the eight-day trial period (Figure 3B). Reactive SLYME BART ${ }^{\mathrm{TM}}$ test vials were cloudy and/or contained black growth suspended in the vial or situated at the bottom of the vial (Figure 4A). Non-reactive SLYME BART ${ }^{\mathrm{TM}}$ test vials remained transparent, with the yellow/tan nutrients initially in the bottom of the vial gradually diffusing upward over the course of the eight-day trial period (Figure 4B). The day on which each test vial was considered positive is presented in Table 2.

The approximate size of the bacterial population detected in the UV treated samples was indicated by number of days until the start of

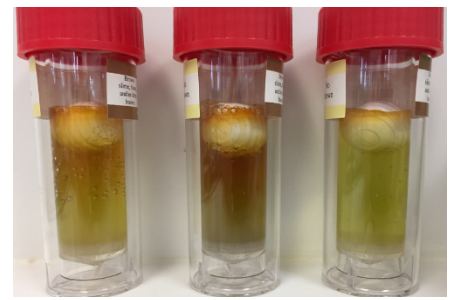

Figure 3A: Day 8 of reactive BART ${ }^{\mathrm{TM}} \mathrm{IRB}$ test vials subjected to $0 \mathrm{~mJ} / \mathrm{cm}^{2}$ treatment i.e., control group. Triplicates, vials $A-C$ shown from left to right.

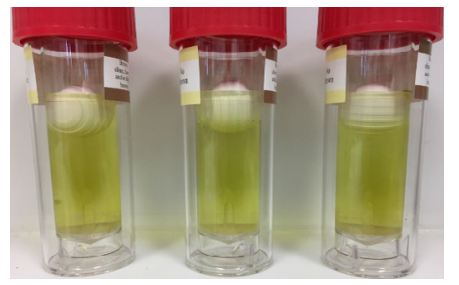

Figure 3B: Day 8 of non-reactive BART ${ }^{\mathrm{TM}}$ IRB test vials subjected to $45 \mathrm{~mJ} / \mathrm{cm}^{2}$ UV treatment. Triplicates, vials A-C shown from left to right.

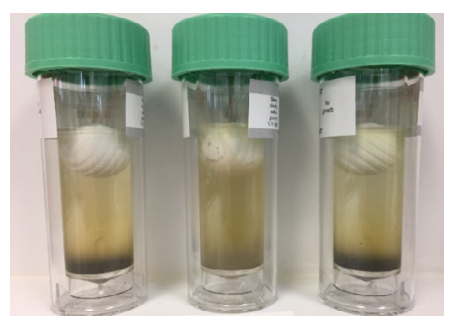

Figure 4A: Day 8 of reactive BART ${ }^{\mathrm{TM}}$ SLYME test vials subjected to $0 \mathrm{~mJ} / \mathrm{cm}^{2}$ UV treatment i.e., control group. Triplicates, vials A-C shown from left to right.

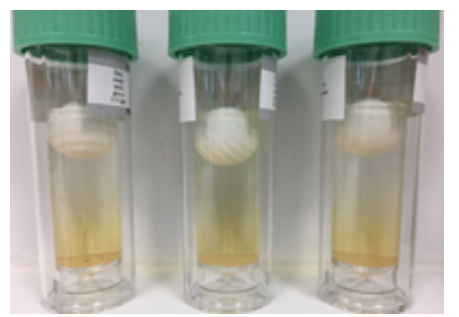

Figure 4B: Day 5 of non-reactive BART ${ }^{\mathrm{TM}}$ SLYME test vials subjected to $30 \mathrm{~mJ} /$ $\mathrm{cm}^{2}$ UV treatment. Triplicates, vials A-C shown from left to right.

\begin{tabular}{|c|c|c|c|c|c|c|}
\hline \multicolumn{2}{|c|}{ Variables } & $0 \mathrm{~mJ} / \mathrm{cm}^{2}$ & $15 \mathrm{~mJ} / \mathrm{cm}^{2}$ & $30 \mathrm{~mJ} / \mathrm{cm}^{2}$ & $45 \mathrm{~mJ} / \mathrm{cm}^{2}$ & $60 \mathrm{~mJ} / \mathrm{cm}^{2}$ \\
\hline \multirow{3}{*}{ IRB } & A & 5 & 6 & -- & -- & -- \\
\hline & B & 5 & 8 & 7 & -- & -- \\
\hline & C & 6 & 5 & -- & -- & $\mathrm{N} / \mathrm{A}$ \\
\hline \multirow{3}{*}{ SLYME } & A & 3 & 6 & -- & 6 & 4 \\
\hline & B & 2 & -- & 6 & 5 & 8 \\
\hline & C & 3 & 8 & 7 & 4 & 6 \\
\hline
\end{tabular}

Table 2: Days to reaction indicative of bacteria presence for BART ${ }^{\mathrm{TM}}$ IRB and SLYME test vials. -- indicates non-reactors. Only duplicate BART ${ }^{\mathrm{TM}}$ IRB test vials analyzed for $60 \mathrm{~mJ} / \mathrm{cm}^{2}$ treatment group.

a reaction [13], a longer time until positive reaction being indicative of lower bacterial population sizes remaining after UV treatment. Approximate populations in $\mathrm{CFU} / 100 \mathrm{~mL}$ for $\mathrm{BART}^{\mathrm{TM}} \mathrm{IRB}$ and SLYME test vials are presented in Table 3. 
The results of this study suggest that UV treatment decreases the likelihood of iron bacteria to survive, with the highest percent of nonreactive BART ${ }^{\mathrm{TM}}$ test vials resulting from $45 \mathrm{~mJ} / \mathrm{cm}^{2}$ and $60 \mathrm{~mJ} / \mathrm{cm}^{2}$ UV exposure (Figure 5). Data for IRB BART ${ }^{\mathrm{TM}}$ test vials suggested a statistically significant $(\mathrm{p}=0.007)$ relationship between increasing UV dose and time-to-failure, and a hazard ratio equal to 0.9054 indicating the risk of failure (i.e., positive $\mathrm{BART}^{\mathrm{TM}}$ result) decreases with increasing

\begin{tabular}{|c|c|c|c|c|c|c|}
\hline \multicolumn{2}{|c|}{ Variables } & $0 \mathrm{~mJ} / \mathrm{cm}^{2}$ & $15 \mathrm{~mJ} / \mathrm{cm}^{2}$ & $30 \mathrm{~mJ} / \mathrm{cm}^{2}$ & $45 \mathrm{~mJ} / \mathrm{cm}^{2}$ & $60 \mathrm{~mJ} / \mathrm{cm}^{2}$ \\
\hline \multirow{3}{*}{ IRB } & A & 2,300 & 500 & 0 & 0 & 0 \\
\hline & B & 2,300 & 25 & 150 & 0 & 0 \\
\hline & C & 500 & 2,300 & 0 & 0 & $N / A$ \\
\hline \multirow{3}{*}{ SLYME } & A & 100,000 & 1,200 & 0 & 1,200 & 18,000 \\
\hline & B & 700,000 & 0 & 1,200 & 5,000 & 200 \\
\hline & C & 100,000 & 200 & 500 & 18,000 & 1,200 \\
\hline
\end{tabular}

Table 3: Approximate population in CFU/100 $\mathrm{mL}$ for BART ${ }^{\mathrm{TM}}$ IRB and SLYME test vials following manufacturer's estimates based on days until reaction. A longer time lag was indicative of a less dense population size. Only duplicate BART ${ }^{\mathrm{TM}}$ IRB test vials analyzed for $60 \mathrm{~mJ} / \mathrm{cm}^{2}$ treatment group.

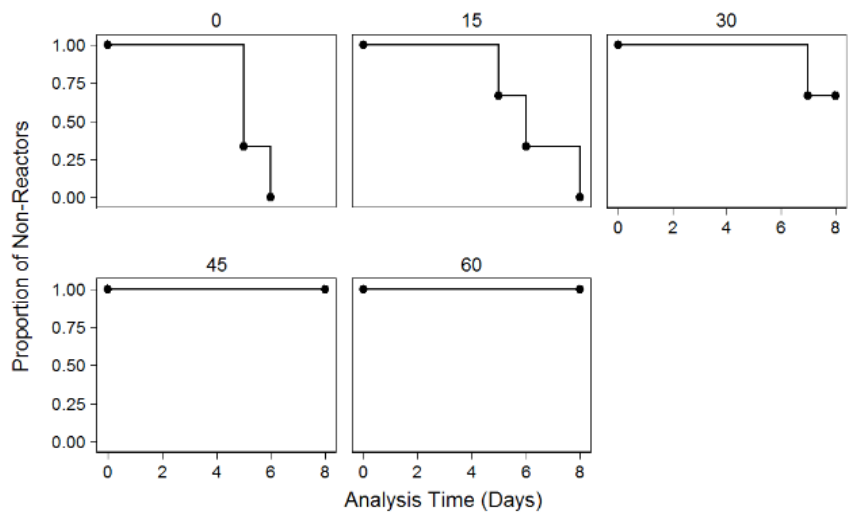

Figure 5: Kaplan-Meier survival estimates, by dose of each IRB BART test vial. Non-reactors indicate the absence of iron related bacterial growth. Analysis time in days.

\begin{tabular}{|c|c|c|c|}
\hline UV Target & Hazard Ratio & SE & $\mathbf{p}>|\mathbf{z}|$ \\
\hline IRB & 0.9054 & 0.0335 & 0.007 \\
\hline SLYME & 0.9947 & 0.0156 & 0.733 \\
\hline
\end{tabular}

Table 4: Cox Proportional Hazards Model for IRB and SLYME BART vials. P value less than 0.05 indicates statistically significant relationship between increasing UV dose and probability of no reaction, i.e., absence of bacterial grow.

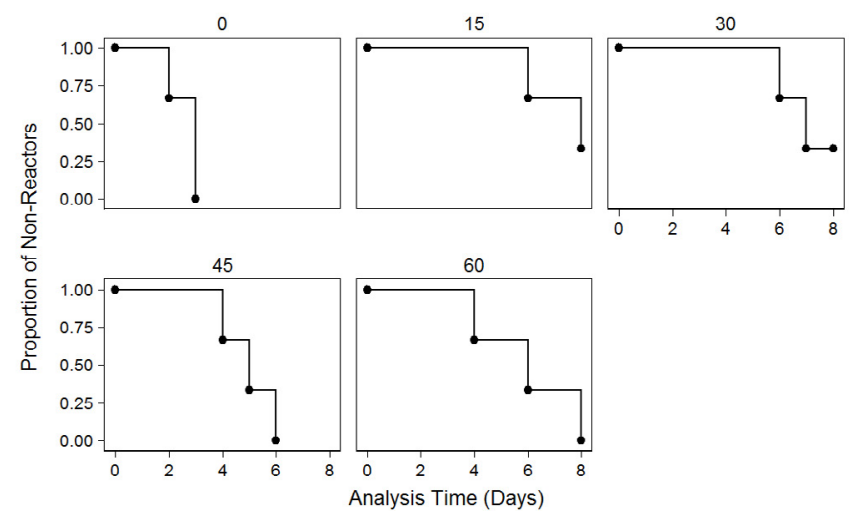

Figure 6: Kaplan-Meier survival estimates, by dose of each SLYME BART test vial. Non-reactors indicate the absence of slime forming bacterial growth. Analysis time in days.
UV dose (Table 4). Examination of Schoenfeld residuals indicated that proportional hazards model assumptions were met.

These results indicate that iron-related bacteria could be significantly reduced in raw well water by treatment with UV at a minimum dose of $45 \mathrm{~mJ} / \mathrm{cm}^{2}$. This effect does not mean that iron-related biofilm growth and associated issues would be eliminated, but it provides a method to address the bacteria at the source of the biofilm. Treatment of the well water at a UV dose less than $45 \mathrm{~mJ} / \mathrm{cm}^{2}$ did not prove effective at decreasing the likelihood that iron-related bacteria would survive treatment. The lower dose may not have penetrated any shadowing particulates or provided the irradiation necessary to damage bacterial DNA and prevent reproduction.

The relationship of increasing UV dose and time-to-failure was not present with the SLYME BART ${ }^{\mathrm{TM}}$ tests. Due to positive SLYME BART $^{\mathrm{TM}}$ test results after exposure to $45 \mathrm{~mJ} / \mathrm{cm}$ and $60 \mathrm{~mJ} / \mathrm{cm}$ (Figure 6), data were inconclusive and did not suggest a statistically significant relationship between increasing UV dose and probability of no reaction $(\mathrm{p}=0.733)$ (Table 4). Examination of Schoenfeld residuals, however, indicated that proportional hazards model assumptions were not met when using the available data. Also, although the testing was randomized, the $60 \mathrm{~mJ} / \mathrm{cm}^{2}$ treatments were the final tests, at which time the original sample volume was low. Although care was taken to avoid pipetting particulates out of the sample when its volume was reduced, the possibility that this occurred nonetheless and subsequently influenced testing results must be considered.

Excessive bacterial biofilms in fish hatcheries can result in operational problems that include, among other things, (i) biofilm growth inside fish culture units, necessitating frequent cleaning, (ii) clogging of fish culture unit exclusion screens, leading to water flow restriction, (iii) high total suspended solids that compromise fish health, (iv) clogging of unit process equipment and resulting reductions in process efficiencies, and (v) clogging of well screens and subsequent groundwater well failure. Iron bacteria in fish hatchery water supply systems are often the cause of excessive bacterial biofilms. Hatchery bioengineers and operators have limited treatment options to address iron bacteria biofilms. Shock chlorination to kill iron bacteria can be used when the water supply system is offline and not supplying water for fish culture. There are no simple alternatives in practice, however, that are known to reduce iron bacteria and associated biofilm growth that occurs during hatchery operation. This study sought to determine if UV treatment could be used to address the issue. UV treatment is a relatively simple and commonly used disinfection process in fish hatchery water supply systems.

The results of this research suggest that UV treatment is an effective method of inactivation for iron-related bacteria in well water supplies for fish hatcheries. The minimum dose suggested for treatment is 45 $\mathrm{mJ} / \mathrm{cm}^{2}$. These initial 'proof of concept' findings can be used to design pilot UV water treatment systems for fish hatcheries known to have iron bacteria problems. Pilot treatment system testing can then provide the results needed to ensure that UV treatment is effective against sitespecific iron bacteria populations before full-scale treatment systems are implemented.

\section{Conclusion}

The data generated on the response of slime-forming bacteria to UV exposure were not conclusive, and therefore assumptions cannot be made regarding the treatment of slime-forming bacteria. If slimeforming bacteria are the source of excessive biofilms in fish hatcheries, then higher UV doses may be required to address the issue. Future 
Citation: Redman N, Good C, Vinci BJ (2017) Assessing the Utility of Ultraviolet Irradiation to Reduce Bacterial Biofilms in Fish Hatchery Well Water Supplies. J Aquac Res Development 8: 501. doi: 10.4172/2155-9546.1000501

Page 5 of 5

research is suggested to definitively determine the effectiveness of UV treatment against slime-forming bacteria.

\section{Acknowledgements}

The authors thank Thomas E. Kielbasinski of the New York State Department of Environmental Conservation Salmon River Fish Hatchery for his cooperation on this study.

\section{References}

1. Mogg JL (1972) Practical corrosion and incrustation guide lines for water wells. Ground Water 10: 6-11.

2. Cullimore DR, McCann AE (1978) The identification, cultivation and control of iron bacteria in ground water. London: Academic Press, Inc.

3. Smith SA, Tuovinen $\mathrm{OH}$ (1985) Environmental analysis of iron-precipitating bacteria in ground water and wells. Ground Water Monit Remediat 5: 45-52.

4. Kucera S, Wolfe RS (1957) A selective enrichment method for Gallionella ferruginea. J Bacteriol 74: 344.

5. Starosvetsky D, Armon R, Yahalom J, Starosvetsky J (2001) Pitting corrosion of carbon steel caused by iron bacteria. Int Biodeterior Biodegradation 47: 79-87.

6. Hasselbarth U, Ludemann D (1972) Biological incrustation of wells due to mass development of iron and manganese bacteria. Water Treatment and Examination 21: 20-29.

7. Harif T, Elifantz H, Margalit E, Herzberg M, Lichi T, et al. (2011) The effect of UV pre-treatment on biofouling of BWRO membranes: A field study. Desalin Water Treat 31: 151-163.

8. Schafer DC (1974) The right chemicals are able to restore or increase well yield. The Johnson Drillers' Journal 1-4: 13.

9. Harris GD, Adams VD, Sorensen DL, Curtis MS (1987) Ultraviolet inactivation of selected bacteria and viruses with photoreactivation of the bacteria. Water Res 21: 687-692.

10. Bolton JR, Linden KG (2003) Standardization of methods for fluence (UV dose) determination in bench-scale UV experiments. J Environ Engineer 129: 209-215.

11. Hach Company (2003) DR/4000 Spectrophotometer Procedures Manual, (11th edn). Hach Company, USA.

12. American Public Health Association (APHA) (1995) Standard methods for the examination of water and wastewater, $19^{\text {th }}$ ed. American Public Health Association (APHA), Washington DC, USA.

13. Droyon Bioconcepts Inc. (DBI) (2004) Biological Activity Reaction Test BARTTM User Manual. Droyocon Bioconcepts Inc., Regina, Saskboltonatchewan, Canada. 